\title{
HOW CAN STUDENTS-TEACHERS ACQUIRING COMPETENCES FROM LECTURE AND SEMINAR ACTIVITIES BY PROMPTING DIDACTIC PRINCIPLES
}

\author{
Darinka Sikosek \\ University of Maribor, Slovenia
}

\begin{abstract}
This study is focused on the curricular innovations of methodological subjects for acquiring of teachers competences at undergraduate education where students as prospective chemistry teachers serve as a goal group. The redesign of the curricular forms thus introduced (such as Lectures, Seminars, Didactic/Laboratory Practical Courses and Mentor work) is based on consistent consideration of topical didactic principles. Research into the optimal forms for curriculum performance focuses particularly on their organisation, methodology and evaluation. These three model parameters serve to implement student activity and autonomy, goal-oriented process learning and democratic relations to ensure realisation of the competences necessary for carrying out the teaching and learning model. The active development and acquisition of subject didactic competences is accompanied by three issues: "What? How? Why? and the following infinitives: "to preserve, to innovate and to abandon".
\end{abstract}

Key words: teaching skills and competences, student autonomy, didactic principles, curricular forms of methodological programme.

\section{Introduction}

You can always find many professors that teach what should be done, but there are very few of them who teach how something should be done. (Michel Quoist)

The above quotation was chosen as a guide to thinking how this "how" should be achieved during the process of education and training of teachers. Because modern society we faces updated individual needs, the pre-existing traditional, descriptive content-oriented ap-proach without precise analysis and intense content interpretation is no longer sufficient and it needs to be replaced by the process model of teaching.

To carry out the process model of teaching with an active role for students as a prime characteristic of the teaching process, we need appropriate teacher qualifications in the area of subject knowledge as well as teaching skills. New and rapidly changing teacher roles and tasks represent a serious challenge to the existing routine of regulated teaching (Driel, 2005).

The varying needs of the contemporary market such as critical literacy, technological and ecological awareness and efficient communication require undeniable co-responsibility from learners formation of desired professional profiles. The actual needs of an individual, as an active member of various social and professionals networks must take precedence over the current pattern of educational provision (Manolescu, 2006). However, the labour market problems and academic standards create the required curricular changes of various study programmes (Ash, 2006).

The essential element of verification of the quality of future employees is represented by student self-evaluation of capacity to fulfil the needs of chosen or desired jobs. How to establish student self-evaluation of potential employability on the basis of his/her surface learning and the imitative nature of acquired knowledge or acquired competences represents an open question for expert debate from the point of view of the teacher's capacity, and leads directly to this didactic anomaly. 


\section{New challenges}

Quality education and training has been represented as an indispensable factor in building the "Europe of Knowledge", but it remains unattainable without quality education and training for the teachers who participate in programs of initial education or in preparation for a teacher's licence PAI-Pedagoško Andragoško Izobraževanje (Continuing Teacher Certifi-cation), as well as enhancement programs that enable teachers to get permission to teach in new subject fields (Theses for renovation syllabus, 2004; Zgaga, 2004). At the same time, we can not overlook the various permanent professional pedagogical education programs (either subject or methodological).

The answer to the needs of a future employee as a member of the European Union is provided by models of teacher education according to the principle of fundamental competence. Starting from the definition of employee competences, according to various authors, the undeniable principle in that of competences as the ability to manage instruments / tools / procedures that enable the selection, processing and the use of information (Razdevsek Pucko, 2004).

The concretization of teacher competences in the search for a job (according to Perrenoud) means the »qualification of individuals for mobilization, use and integration of acquired knowledge in complex, different and unexpected situations « (Project Tuning 20002004, Theses for renovation syllabus, 2004).

Originating with the Tuning Project 2000-2004, which actualizes the Bologna process (Bologna Declaration, 1999), one of the key aims of program tuning within the European Higher Education Area (Keeling, 2006) is: »to develop professional profiles of comparable and compatible learning results. «The document, called Berlin Communique (2003) obliges indi-vidual ministries to prepare detailed expert report on qualifications, including descriptions of work obligations, educational levels, study results, competences and profiles.

Following basic educational trends, the methodology of tuning also includes and thus works towards the following paradigm: a shift in the process from faculty and staff towards students, towards what an employed graduate should know, understand and do (Floud, R., 2006). Following this methodology, we differenciate between generic (Towards the European Higher Education Area Bologna Process, 2004; Gemlich, 2004) and subject specific compe-tences (Tuning Cycle Descriptors in Tuning educational structures in Europe-Phase II). The following three types of generic competences are defined: Instrumental, Systemic and Inter-personal competences. In addition, each of these types is further classified by different charac-teristic abilities (competences) (General Presentation of Tuning Methodology in Tuning Pro-ject 2000-2004).

Determining the proportion of competences of each type included in the formation of a teacher profile is the responsibility of key partners in the education-training process: graduates, school principles as employers, and high-school teachers as educators. During implementation, the building of pedagogical programs must ensure the active development and acquisition of the necessary generic and subject-didactic competences (Key Competences, 2002) for this professional profile. The main stress in study programs is placed on study achievements, the student-centred process and flexibility, these being the requirements of a society of life-long learning; therefore the creators are obliged to take joint responsibility for the competence quality of teachers receiving the certificate to teach e.g. in Chemistry.

\section{The purpose and aims of this research}

These new challenges demand the redesign of initial instruction as well as the training of Chemistry teachers that is carried out by means of the model of a methodological module as a combination of Lectures and Seminar work, Practical Courses/Mentor work, Lesson 
Observations and the Performance of independent study, i.e. assessed lessons and Teaching Practice (hereafter abbreviated as Lec-Sem-Prac/Men-ObsPerTeaPrac). The primary operative aims (Univerzitetni pedagoski dvopredmetni program »Kemija in ...« ,1996; Univerzitetni pedagoski enopredmetni program »Kemija« ,1994) that lead to achieving this purpose are mostly the following:

1. to study the appearance of generic competences and to define subject-specific competences that could be realised within the above mentioned curricular forms of the trio of methodological subjects: Didactics of Chemistry, Experiments and natural activitiesMentorship (hereafter abbreviated as DCEM);

1. to define and optimise the multiple teaching roles of students, who act as (a) active listeners at lectures, (b) performers of seminar tasks, (c) performers of exercises through practical courses and mentor work, (d) lesson observers and teachers through observation, teachers of individual assessed lessons and teaching practice;

2. to improve the paradigm of active education and training of chemistry teachers as thinking professionals in practice. In realising this paradigm, feedback or the results of reflective practice (hereafter abbreviated as $\mathrm{Fb}$ ) from students (in the roles specified in above) must be correlated with the defined competences of graduates (aim 1);

4. to impart to future chemistry teachers the need for continuous reflective practice accompanied by subsequent individual action plans.

\section{Analysis of potential competences for the methodological subject module of the Chemist-ry education study program}

Some characteristic "teacher" competences (Sikosek,1997,2003) that are developed during students' active participation in performing various activities from the above mentioned curricular forms of the DCEM methodological subject module are presented in continuation.

Student learning outcomes by subject Didactics of Chemistry (Univerzitetni pedagoski dvopredmetni program »Kemija in ...«,1996; Univerzitetni pedagoski enopredmetni program »Kemija«, 1994)

key aims didactic verbs-students:

to be master of, to be qualified to, to be able to use/realise,...

subject-specific teaching competences

(1)various aims and activities (Lec, Prac, Perf, TeaPrac) according to Bloom's taxonomy; (2)content and methodology of elementary and secondary Chemistry education (Lec, Prac, Perf, TeaPrac); (3)interdisciplinary (a) connecting content, (b)pair/team work\&teaching (Lec, Sem, Prac, Perf, TeaPrac); (4)organizing and planning teacher tasks (Prac, Perf, TeaPrac); (5) initiative, creative and autonomous agency (Sem,Prac,Perf,TeaPrac); (6)(self)critical and (self)reflexive approach or (self)evaluation of lesson quality (Prac, Perf, TeaPrac); controlling \& assessing student achievements and providing feedback (Lec, Prac, Perf, TeaPrac); (8)adapting to new didactic situations (Prac, Perf, TeaPrac); (9)informational-communicational technology (Lec, Sem, Prac, Perf, TeaPrac).

\section{transferable competences}

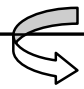

(1)organizing and performing teaching skills (Prac-Perf-TeaPrac); (2)verbal and nonverbal communication skills (Prac, Perf, TeacPrac); (3)oral/written communication and cooperative/team work with others(teachers, professionals);(4)organisational and management skills in the educational process (Sem); (5)project planning and management (Sem); (6) (self)critical (self)analysis and evaluation of teaching and other activities (Sem, Prac,Perf, TeacPrac); (7)interpersonal skills (Sem). 
Student learning outcomes by subject Experiment (Univerzitetni pedagoski dvopredmetni program »Kemija in ...«, 1996; Univerzitetni pedagoski enopredmetni program »Kemija«, 1994)

key aims didactic verbs-students:

to be master of, to be qualified to, to be able to use/realise,...

\section{$\rightarrow$ subject specific teaching competences}

(1)content and methodology of experimental lesson for elementary (grades 7-9) and secondary

Chemistry education (Lec-Sem-LabDidPrac*); (2)handling lab inventory and chemicals ( Lec,

LabDidPrac); (3)experimental skills for basic safe lab work (LabDicPrac);(4)the reflective approach to experimental lessons (Obse, TeaPrac); (5) the self-critical approach to quality performance of lab work ( LabDidPrac); (6)individual/pair /group experimental teaching (Lec,Obser,LabDidPrac); (7) developing new experiments through team work (Sem,LabDicPrac) informational-communicational technology (Lec,Sem,Prac,Perf,TeaPrac); (8)evaluation of students' experimental work (Sem ). *LabDidPrac-Laboratory Didactic Practicum

\section{$\rightarrow$ transferable competences}

(1)methodological knowledge; organizational and practical teaching skills through the problem solving method (Sem,LabDidPrac); (2)verbal and nonverbal communication skills about experimental teaching (LabDidPrac); (3)project planning and management experimental chemistry education (Sem).

Students learning outcomes by subject natural activities-Mentorship (Univerzitetni pedagoski dvopredmetni program »Kemija in ...«, 1996; Univerzitetni pedagoski enopredmetni program »Kemija «,1994)

key aims didactic verbs-students as mentors:

to be master of, to be qualified for, be able to use/articulate/realise

\section{$\rightarrow$ subject specific teaching competences}

(1) the content and methodology of mentor work in various natural programs of elementary and secondary Chemistry education (Lec,Sem,Men); (2) team development of integrated interdisciplinary content and collaborative performance of new approaches (Men); (3) Mentor Preparation (Sem); (4) the self- critical approach to quality in performance of mentor work (Men); (5) self-evaluation of quality of seminar work reports (Sem).

\section{$\rightarrow$ transferable competences}

(1) ability to demonstrate initiative as well as ambitious, creative and autonomous activity as a mentor (Men); (2) ability to organize research projects (Sem,Men); (3) ability to adapt to new didactic situations (Sem,Men); (4) development of interpersonal communication (Men).

\section{Implementation modifications to student lecture and seminar activities in the methodo- logical subject module DCEM according to Bologna model.}

* $\mathrm{A}^{2} \mathrm{DIDG}$ - Activity, Autonomy, Differentiation and Individualization, Democracy, Gradated study 
The author of this paper is a teacher-trainer who gives lectures and seminars within the methodological subject module DCEM, designed for teachers of Chemistry. At the end of semester in these subject programs, I collected useful student feedback about the success of the targeted activities achieved through lecture and seminar work. In advance of this paper some of the teacher-trainer's as well as the students' evaluation findings (Sikosek, 19962004) are given. These opinions were taken into serious consideration through continual performance modification of these curricular forms.

Lectures. In lectures I was very concerned about the overt passivity of students as listeners. As a measure to overcome these weaknesses, and to increase listener activity, I engaged my students as co-lecturers. In this role they participate in the following groupings: a teacher-trainer-student pair, a student-student pair or a student-student team.

Seminars. From previous generations' seminar work, we can identify some poorly planned or even unplanned didactic principles: (1) an authoritatively defined program outline (teacher-trainer) that is the same for all students; (2) a narrowly-defined process aim; (3) activity limited to the role of referent and »passive listener«; (4) insufficient student autonomy; (5) poor levels of student activity; (6) lack of differentiation and individualization. Therefore the goal of the revised activities is defined as follows:

1) training in internal organisation of individual pair as well as individual team work;

2) acquiring the ability to articulate subject didactic material (the learning unit, detailed professional reports, posters/other presentations) while using active learning methods/ forms;

3) training in methodological planning of other activities involved in pedagogical work;

4) introduction to the methodology of self - evaluation of teaching practice as a form of pre-service practical teacher training;

5) introduction to documentation, organizational, coordination-moderator and evaluation work;

6) introduction to the promotion of individual education achievement;

7) training in self-evaluation of seminar work.

The current operational conception of seminar work includes the following "competence activities" for students : (1) work organization, (2) preparation and coordination of subject contributions, (3)moderate performance and (4) archival documentation.

In the interest of work organisation, we form subject working groups of different sizes. Documentary and organizational work is carried out as a pair activity while evaluation work is done by four students, although the task item groups are larger. There are two criteria for forming the size of the latter groups: the extent of task item list and »the competence« weighting of selected content items. In both cases, during preparation and presentation of these tasks, various groupings are in use, including group work where either each member or each pair has his/its own task, that is individual or pair assorted group work.

Two teacher-trainer guidelines (Organisational model of seminar work), namely permanence and flexibility among the roles chosen during the realization of each task, are used in forming these groups. Thus, the documentary and organizational pair, as well as the evaluation group, each has a permanent leader, but the other members of both pairs and of the evaluation group are changeable. Flexibility is also a characteristic of the task group, because each group has its own coordinator as well as other "subject members".

The carrying out of subject roles is achieved through previously defined work and tasks, a process which can be seen in the following survey. 
Key work functions and tasks of working groups

\begin{tabular}{|l|}
\hline \multicolumn{1}{|c|}{ A documentary pair } \\
\hline $\begin{array}{l}\text { (1) keeping records in electronic and hard-copy form; then photo and audio (occasionally video) } \\
\text { documentation; (2) arranging the subject information surface; }\end{array}$ \\
\hline \multicolumn{1}{c|}{ B organizational pair } \\
\hline $\begin{array}{l}\text { (1) preparation of performance plans (in conjunction with coordinators); (2) setting due dates for } \\
\text { performance of seminar work; (3) preparation of final internal planning; }\end{array}$ \\
\hline \multicolumn{1}{c|}{ C evaluating trio } \\
\hline $\begin{array}{l}\text { (1) preparation of assessment criteria and point scale for assessing task presentation and study report; } \\
\text { (2) carrying out evaluation; (3) provision of feedback; }\end{array}$ \\
\hline \multicolumn{1}{c|}{ D coordinators } \\
\hline $\begin{array}{l}\text { (1) supervision/ choice (in cooperation with the task owners) of research sources; (2) coordination of } \\
\text { holder's research work; (3) occasional tasks / specific methods, e.g.: in using a pro and contra } \\
\text { presentation method or round table method, the coordinator is occupied as (a) an announcer of the } \\
\text { moderator's work, (b) communication facilitator: organizer } \leftrightarrow \text { moderator, expert } \leftrightarrow \text { moderator/ (pro } \\
\text { and contra method); (4) or a leader of each item discussion; }\end{array}$ \\
\hline \multicolumn{1}{c|}{ E moderators } \\
\hline $\begin{array}{l}\text { (1) composing a moderator's outline; (2) moderating (leading) the oral presentations of panel } \\
\text { contributions; (3) co-leading (within the expert group) panel discussion; }\end{array}$ \\
\hline \multicolumn{1}{c}{ D coordinators } \\
\hline (1) defining of panel items; (2) composing of execution plan for the panel presentation contributions; \\
\hline \\
\hline $\begin{array}{l}\text { G) researching information sources; (2) studying of selected current sources; (3) drafting a concept for } \\
\text { the item contribution; (4) composing study report; (5) oral presentation of seminar task }\end{array}$ \\
\hline
\end{tabular}

In pursuit of continual improvement in the organizational model for lectures and seminars, I take into consideration the six didactic principles ${ }^{1}$ designated $\mathrm{A}^{2} \mathrm{D}^{2} \mathrm{IG}$, in order to ensure acquisition of the competence, knowledge and skills for the Bologna model teachers. An analysis and interpretation of the operation these principles for carrying of lecture and seminar activities presented below.

\section{The $A^{2} D^{2} I G$ principles and student lecture activity (Sikosek, 2003)}

On the basic of a program outline for a given subject comprising a fixed number of content items ${ }^{2}$ (hereafter designated CI), theoretical (lecture) outline is created, in which the author (taking into account content differentiation) distinguishes between informative and formative knowledge. Within each category of subject knowledge, the author defines applied and new content items (hereafter designated $\mathrm{a} / \mathrm{nCI}$ ). The further stage of content classification is defined as the core and optional CI of a lecture outline for the matriculated generation of the current academic year. In forming this outline, I define core IC (hereafter designed cIC) within each IC, while the students then choose optional CI (hereafter designated oCI) (student autonomy), after which is sought, following the principles democratic principles.

\footnotetext{
${ }^{1} \mathrm{~A}^{2} \mathrm{D}^{2} \mathrm{IP}$ principles: Activity, Autonomy, Differentiaon and Individualisation, Democratization, Gradated study,

${ }^{2}$ Subject Didactics of Chemistry includes 6 CI with the following key words: positional role of chemistry in educational system, programs, content, methods and groupings, educational technology, evaluation.
} 
I have already mentioned the use of students as co-lecturers as being my first preventive measure against low student participation in the lectures (limited to listening and self - regulative construct of »transfer « knowledge). Their choices in the realization of CI and social grouping are completely independent. A running evaluation of the students- as co - lecturers' model (gained from student feedback) confirms greater student interaction with the acquisition of content; however, it also cautions us that only individual students are engaged. To remedy this deficiency a strategy of consulted autonomous study of $\mathrm{CI}^{1}$ is used, including a variety of group work that includes the entire current generation of students who registered in that subject from the DCEM module.

\section{The $A^{2} D^{2} I G$ principles and seminar work (Sikosek, 2003)}

The didactic principle of student autonomy was present in the definition of seminar work from the item outline because the selection of CI is made as a compromise between teacher-trainer's given subject and student expectations. The didactic principle of activity can be recognized when students take over certain roles relevant to the quality performance of their seminar work. With the exception of permanent leaders of working groups, all the other students in the seminar take over the double role; besides being responsible for an autono-mously chosen item, they also take over the role of either co-organizers, coevaluators, or co-documentors, as well as coordinators or occasional moderators. Content and functional diffe-rentiation is also present and is realized through individual-or teacher diferentiated group work, because those responsible for items and functional tasks determine their work on their own, considering their own wishes, needs and capabilities. But because student evaluation of needs and capabilities is necessarily subjective, it is also important that the teacher-trainer guide student decisions about the optimal selection of items and roles with informed opinion. Sequential fulfilment of the process aims, which are realised through targeted competence activities during the winter and spring semesters, demonstrates consideration of the principle of gradated study. Authentic realization activities demanded by the carrying out of an item program (especially the spring program) are connected with a varied palette of complex knowledge processes and skills, e.g. project work or the design of expert's thematic contributions from their own learning experience (mastering the study of relevant literature) carried out within the valid curriculum of pedagogical- psychological didactic education and training ${ }^{2}$.

\section{Example study of materials and equipment for student lecture and seminar activities in taking on teacher's roles according $\mathrm{A}^{2} \mathrm{D}^{2} \mathrm{IG}$ principles}

A key document in the realization phase where students serve as co-lecturers or perform seminar activities is the subject realization plan: (1) Realization Lecture Plan (hereafter RLP) and (2) Realization Seminar Plan (hereafter RSP). Informational on the RLP includes the following: date, item complex / content item, grouping and lecturers, while the RSP, as well as these four parameters, also includes a rearrangement of »functional « roles ( item holders, coordinator/moderator, evaluator, organizer, documenter with co-evaluators/organizers and -documenters). In order to successfully carry out the RLP/RSP target roles

\footnotetext{
${ }^{1}$ Example of such a CI is: The causes of accidents: »Finding out the causes of accidents-Commands, Warnings, Advice for the teacher.

${ }^{2}$ The operative University pedagogical double program "Chemistry and ... (another school subject)" is structured as a parallel model of teacher education in which the first half of the study program contains common pedagogical subjects (Pedagogy, Psychology, Didactics and Multimedia). Moreover in terms of the subject module DCEM there follows application of the acquired subject knowledge as well as branch chemical subjects, the realization of which is continuous.
} 
and competences, the teacher-trainer designs corresponding outlines, namely: (A) Consultation outline for students as the teacher's co-lecturers and (B) Conceptual outlines of actual roles for seminar participants (Sikosek, 2005).

The first outline is used by the teacher-trainer and the student-co-lecturer (who play partner roles) as a guide for preparation on theoretical subject items. But the second is specific to the seminar participant, and provides specific instructions for preparation and carrying of the assigned role (see Key work functions and tasks of working groups).

\section{Conclusions and Implications}

Starting from the new challenges that have been put forward by the mutual European Higher Education Area (EHEA-European Higher Education Area) as the key goal of the Bologna process it has become urgent to re-shape, not only the content but also the structure and especially the methodology of pedagogical programs. In this case the replacement of the data transmission model by the model of process teaching and learning is a key change from the didactic point of view. By Bologna process is conducted a curriculum reform known as a transformation from research to student - centred teaching (Ash, 2006).

Because the Bologna process pays marked attention to the issue of teacher competences

(generic and subject-specific), the opportunity to acquire these needs to be built into all curricular forms of university pedagogical programs, which demands a thorough re-thinking of curricular philosophy. The centerpiece of our critical renovation is the concept of teacher competence located in each curricular form within a methodological module, the trio of subjects DCEM (Didactics of Chemistry, Experiments and Mentorship). Here the various practical modifications started over the past few years are in operation.

The key characteristic of these modifications is represented by a targeted competence approach that appears in managing the process of acquiring didactic (generic) as well as subject-specific (chemical) knowledge and skills. The process planning of program outlines for lectures and seminars conducted in accordance with didactic principles of the types $\mathrm{A}^{2} \mathrm{D}^{2} \mathrm{IG}$. The partnership emphasis of »Bologna process « study, in accordance with the principles of student autonomy and hands-on experience, has been implemented through the introduction of students as co-lecturers. During a seminar program, the students are in charge of various functional roles, through which they acquire extensive generic as well as subject-specific (chemical) competences. This provides clear evidence of the realization of the principle of activity and differentiation with individualization. Of course, the established content consensus of offered (by teacher-trainer) and expected (by students) in lecture and seminar programmes gives proof of performing not only the principle of suitability regarding to professional needs but also a principle of content's exemplification.

In understanding the broad spectrum of generic and subject-specific competences for teachers our efforts have expanded to modification of the topical, curricular forms (Didactic Practicum and Laboratory Didactic Practicum, Observations, Individual Assessed Lessons and Teaching Practice). In the face of such a vision, we can succeed in implementing practical chemistry teacher training that will be in harmony with the motto of the Tuning project: »Mutual accordance of the tuning of educational structures and programs on the basis of diversity and autonomy» (Tuning Project 2000-2004).

\section{References}

Ash Mitchell G. (2006). Bachelor of What, Master of Whom? The Humboldt Myth and Historical Transformation of Higher Education in German-Speaking Europe and the US. European Journal of Education, Vol. 41, No. 2.

Berlin Communique (2003). Realising the European Higher Education Area. Conference of Ministers responsible for Higher Education in 33 European countries (September). 
Bologna Declaration (1999). Towards the European Higher European Area. Conference of Ministers responsible for Higher Education in 29 European countries (June), Bologna, Italy.

Driel van Jan H. (2005) The conceptions of chemistry teachers about teaching and learning in the context of a curriculum innovation. Int. J.Sci.Educ., Vol. 27, No. 3.

Floud R. (2006), The Bologna process: Transforming European Higher Education. Change: The Magazine of Higher learning, Vol. 38, No. 4.

Gemlich V. (2004). Generic Competences. Tuning project II., maj 2004. www publication: http://www.pef.uni-lj.si/strani/bologna/kompetence.pdf.

Keeling R. (2006). The Bologna process and the Lisbon Research Agenda: the European Commission's expanding role in higher education discourse. European Journal of education, Vol. 41, No. 2.

Key Competencies (2002). Survey 5.Brussels: Eurydice, European Unit.

Organisational model of seminar work (D.Sikosek holder guidelines) by subjects Didactics of Chemistry, Experiments of current study years, Chair of Didactics of Chemistry, Faculty of Education, University of Maribor. (Slovene, D. Sikosek holder's nonpublished outline)

Razdevsek Pucko C. (2004). Teachers' Competencies. - www publication: http://www.pef.unilj.si/strani/bologna/kompetence.pdf. (Slovene)

Sikosek D. (2003) Efficiency of Seminarists Activities and didactic principles (Slovene, holder's nonpublished outline).

Sikosek D. (2004) Efficiency of Listener's Activiites and didactic principles (Slovene, holder's nonpublished outline).

Sikosek D. (2005) The Instruments for Performing Listners' and Seminarsts' Roles by using $A^{2} D P$ didactic principles (Slovene, holder's nonpublished material).

Sikosek D. Lectures for Didactics of Chemistry, Experiments and Natural activities-Mentorship, Program outlines /Academic year 2003/04 (Slovene, personal material).

Sikosek D. Methodist Reflexsion (nonpublished authors' evaluation notices of lectures and seminars, performed by subjects Didactics of Chemeistry, Experiments and Science activitiesMentorships in academic terms 1995/96-2003/04), Chair of Didactics of Chemistry, Faculty of Education, University of Maribor. (Slovene, personal material)

Sikosek D. Seminar for Didactics of Chemistry, Experiments and Natural activitiesMentorship, Program outlines /Academic years 1997/98-2003/04. (Slovene, personal material).

Theses for renovation syllabus. www publication: http://pef.pef.uni-lj.si strani/bologna/tuningcycle.pdf (Slovene)

Towards the European Higher Education Area Bologna Process, http:/www.pef.unilj.si/ strani/bologna, 2004.

Tuning Educational structures in Europe-Phase II.Tuning Project working paper. Tuning Cycle Descriptors.- www publication: http://pef.pef.uni-li.si/strani/bologna/tuning-cycle.pdf

Tuning project 2000-2004. General Presentation Of Tuning Methodology. V: Tuning Educational Structures in Europe.- www publication: http://www.pef.uni-lj.si/strani/ bologna/ tuningmethodology.pdf

Univerzitetni pedagoski dvopredmetni program »Kemija in ...« ( Double-major Pedagogical University Study Program «Chemistry and...), Oddelek za kemijo, Pedagoska fakulteta Univerze v Mariboru, (Department of Chemistry, Faculty of Education, University of Maribor), 1996.

Univerzitetni pedagoski enopredmetni program »Kemija« ( Single-major Pedagogical University Study Program «Chemistry«, Oddelek za kemijo, Pedagoska fakulteta Univerze v Mariboru, (Department of Chemistry, Faculty of Education, University of Maribor), 1994.

Zgaga P. (2004) New opportunites for teachers' education... www publication:-http://pef.pef. uni-lj.si/strani/bologna/priloznost-ucitelji-eu-slo-svn-t07.pdf (Slovene)

Received 21 February 2008; accepted 9 March 2008

\begin{tabular}{|l|}
\hline$\square$ \\
\end{tabular}$\quad \begin{aligned} & \text { Darinka Sikosek, } \\
& \text { Department of Chemistry, University of Maribor, Smetanova Street 17, } \\
& \text { 2000 Maribor, Slovenia. E-mail: darinka.sikosek@uni-mb.si } \\
& \text { Website: http://www.uni-mb.si/ }\end{aligned}$

